\title{
WYKLUCZENIE FINANSOWE I INTEGRACJA FINANSOWA - ASPEKTY TERMINOLOGICZNE
}

\section{Wprowadzenie}

Wykluczenie finansowe stanowi jeden z poważniejszych problemów ekonomicznych, mających swoje odbicie w sferze społecznej. Brak możliwości korzystania z usług i produktów oferowanych przez system finansowy może być istotnym czynnikiem prowadzącym do wykluczenia społecznego. Celem artykułu jest zaprezentowanie zjawiska wykluczenia finansowego w Polsce, z uwzględnieniem analizy elementów, które mogą być wykorzystane do pomiaru stopnia wykluczenia finansowego oraz zdefiniowania najbardziej wrażliwych obszarów tego zjawiska.

Ponadto artykuł jest próbą wskazania wielowymiarowości problemu, jakim jest wykluczenie finansowe, oraz poszukiwaniem odpowiedzi na pytanie, czy bierne posiadanie konta lub lokaty jest pełną inkluzją finansową. Na potrzeby artykułu pojęcie systemu finansowego będzie ograniczone do dwóch grup podmiotów. Pierwsza reprezentuje stronę podażową, tj. banki komercyjne, banki spółdzielcze, kasy oszczędnościowe. Druga grupa reprezentuje stronę popytową, tj. klientów indywidualnych/nieprofesjonalnych uczestników rynku finansowego. Obydwie grupy odgrywają istotną, aczkolwiek nie równorzędną rolę na rynku finansowym. Klienci indywidualni nie mając dostępu do odpowiedniej wiedzy, ani możliwości analizowania danych, są bardziej narażeni na skutki błędnych decyzji finansowych. Natomiast strona podażowa dysponuje środkami, które mają decydujący wpływ na tworzenie mechanizmów zabezpieczających nieprofesjonalnych uczestników rynku finansowego.

Przeciwdziałanie wykluczeniu finansowemu wpisuje się w politykę zrównoważonego rozwoju. Dostęp do produktów finansowych oferowanych przez banki to podstawowy warunek codziennej egzystencji każdego obywatela, który jednocześnie przekłada się na harmonijny rozwój społeczności, również w wymiarze makro.

\footnotetext{
* Absolwentka studiów doktoranckich w Kolegium Ekonomiczno-Społecznym, pracownik Narodowego Banku Polskiego.
} 
Komisja Europejska opracowała dokument „Zielona księga w sprawie detalicznych usług finansowych. Lepsze produkty, szerszy wybór i większe możliwości dla konsumentów i przedsiębiorstw”, w którym podjęto "próbę stwierdzenia, jakie konkretne bariery utrudniają konsumentom i przedsiębiorstwom pełne korzystanie $\mathrm{z}$ jednolitego rynku, a także określenia sposobów na pokonanie tych barier, $w$ tym za pomocą jak najlepszego wykorzystania nowych technologii przy zapewnieniu odpowiednich zabezpieczeń"

\section{Rola systemu finansowego w gospodarce}

A. Matysek-Jędrych ${ }^{2}$ wskazuje, że „System finansowy jest układem wzajemnie powiązanych instytucji finansowych, rynków finansowych oraz elementów infrastruktury systemu finansowego; poprzez ten układ podmioty sfery realnej (przede wszystkim gospodarstwa domowe, przedsiębiorstwa i rząd) mogą pozyskiwać fundusze, inwestować oszczędności oraz zaspokajać pozostałe potrzeby związane z finansową sferą funkcjonowania”. System finansowy współistnieje poprzez sieć powiązań z systemem prawnym oraz systemem politycznym, niemniej jego cechą wyróżniającą jest „mechanizm, dzięki któremu świadczy się usługi pozwalające na krążenie siły nabywczej w gospodarce [...]. Rezultatem istnienia systemu finansowego jest możliwość współtworzenia pieniądza przez niefinansowe podmioty gospodarcze (przedsiębiorstwa, gospodarstwa domowe) oraz możliwość przepływu strumieni pieniężnych między nimi”’3. Przytoczone definicje pokazują rozciągłość i wielowymiarowość mechanizmu, jakim jest system finansowy. System bankowy jako jeden z podmiotów systemu finansowego będzie omawiany w artykule w kontekście wykluczenia finansowego. Polski system bankowy w odpowiedzi na transformację ustrojową na przestrzeni ostatnich dwudziestu siedmiu lat uległ szybkim przeobrażeniem.

Przystąpienie Polski do Unii Europejskiej wymagało harmonizacji polskiego prawa bankowego z prawem Unii Europejskiej, a więc dostosowania krajowego sektora bankowego do obowiązujących w UE standardów oraz przygotowania odpowiedniej oferty produktów i usług, zaś fundusze unijne są dodatkowym czynnikiem,

\footnotetext{
1 Zielona księga w sprawie detalicznych usług finansowych. Lepsze produkty, szerszy wybór i większe możliwości dla konsumentów i przedsiębiorstw, Bruksela, dnia 10.12.2015 r., COM(2015) 630 wersja ostat., Sekcja 1.1.

2 System finansowy - definicje i funkcje, „Bank i Kredyt” październik 2007, s. 41.

3 System finansowy w Polsce, red. nauk. B. Pietrzak, Z. Polański, B. Woźniak, PWN, Warszawa 2006, Z. Polański, rozdz. I „Wprowadzenie. System finansowy we współczesnej gospodarce rynkowej”.
} 
który znacząco wpłynął na rozwój sektora bankowego. Tworzone w Unii Europejskiej standardy opierają się na następujących zasadach:

- „identyczności podstawowych wymogów oraz procedur licencjonowania banków oraz wspólnego minimalnego zakresu nadzoru bankowego; tzw. zasada jednolitego paszportu;

- sprawowania nadzoru nad oddziałami banków w innym państwie członkowskim przez nadzór, który udzielił licencji;

- wymiany informacji między władzami nadzorczymi państw członkowskich;

- regulowaniu tylko tego, co nie może być uregulowane przez ustawodawstwo poszczególnych państw, tzw. zasada pomocniczości (subsydiarności);

- zezwolenia na stosowanie ostrzejszych niż powszechnie przyjęte norm ostrożnościowych; tzw. minimum harmonizacji;

- poszukiwania wspólnego mianownika dla interesu ekonomicznego każdego uczestnika rynku; tzw. zasada równego traktowania uczestników rynku”4.

O wzroście roli sektora bankowego w gospodarce świadczy systematyczny wzrost udziału aktywów tego sektora w PKB przedstawiony na rysunku 1. W 1999 r. udział wynosił 55\%, natomiast w 2016 r. zanotowano wzrost do 92\%. Z kolei udział w PKB kredytów dla gospodarstw domowych w okresie 1999-2016 wzrósł z 16\% do 36\%, a depozytów z 24\% do 39\%. Pomimo znaczącego wzrostu udziału sektora bankowego w PKB nadal można wyróżnić wskazane przez Jana Krzysztofa Solarza następujące luki (bariery) w rozwoju systemu finansowego w Polsce:

- „luka kapitałowa, wiążąca się z niedokapitalizowaniem instytucji kredytowej oraz z brakiem krajowych funduszy (oszczędności) finansowania prowadzenia unowocześniających inwestycji,

- luka efektywnościowa będąca stosunkiem poziomu kosztów zatrudnienia do udziału kosztów ogólnych w przychodach banków,

- luka instytucjonalna rozumiana jako brak instytucji właściwych dla dojrzałej gospodarki rynkowej"s.

Zagadnienie wykluczenia finansowego będzie omawiane w odniesieniu do osób fizycznych/nieprofesjonalnych uczestników rynku finansowego, a więc w kontekście bankowości charakteryzującej się uniwersalizmem w realizacji operacji bankowych, czyli w segmencie bankowości detalicznej. Charakterystyczną cechą bankowości detalicznej jest uwzględnienie szerokiego i zróżnicowanego wachlarza potrzeb klientów indywidualnych, co z kolei obliguje banki do poszerzenia oferty produktów.

4 System finansowy w Polsce, red. nauk. B. Pietrzak, Z. Polański, B. Woźniak, PWN, Warszawa 2008, J.K. Solarz, rozdz. XXII „Zakończenie. Krajowy system finansowy wobec globalizacji”.

5 Ibidem. 


\section{Rysunek 1. Udział sektora bankowego w PKB (w \%)}

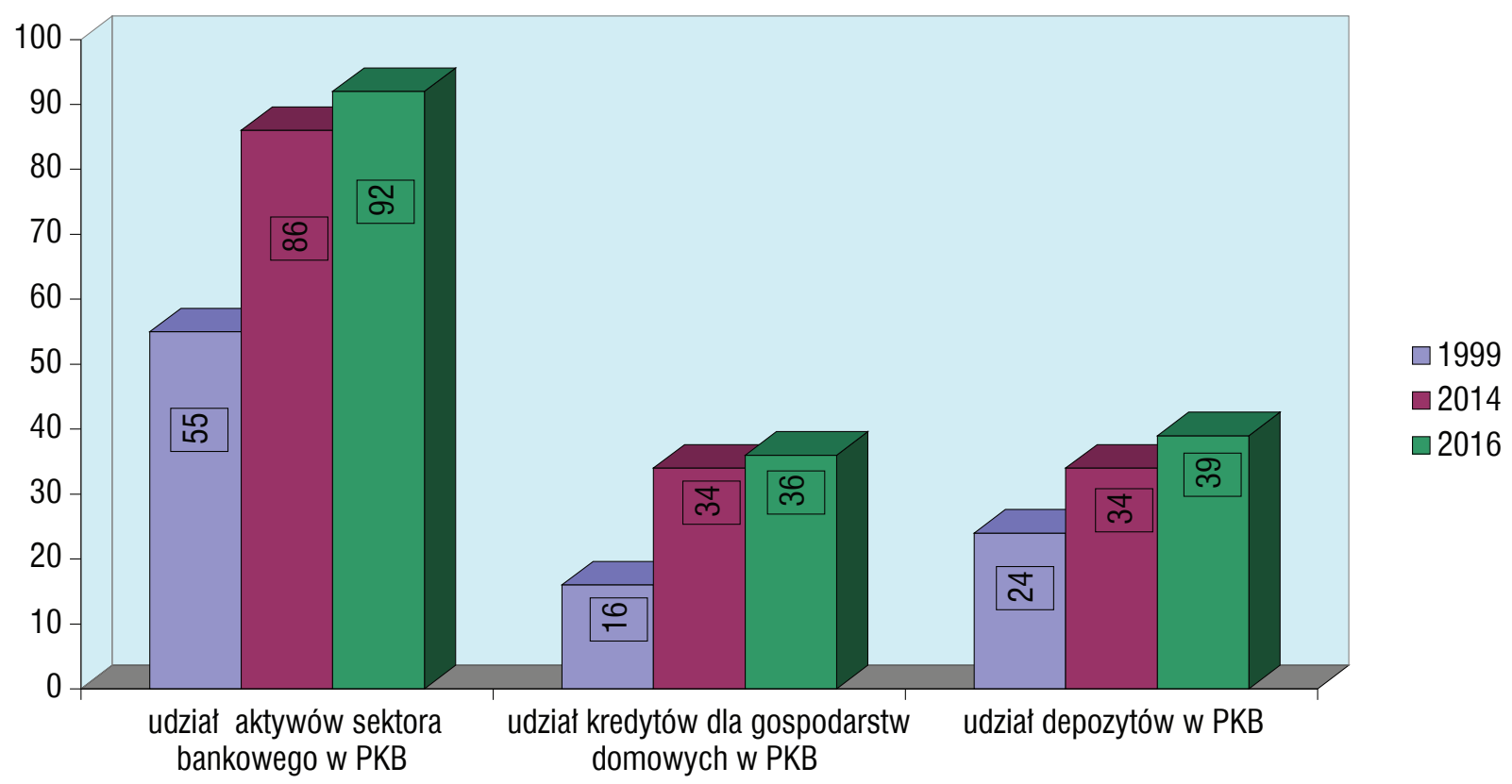

Źródło: KNF, Raport o sytuacji banków 2016.

\section{Wykluczenie finansowe}

Sektor bankowy jako reprezentant strony podażowej ponosi odpowiedzialność za przygotowanie oferty, która pozwoli na zaspokojenie potrzeb klientów. Akceleracja procesów zachodzących w gospodarce czyni niemożliwym osiągnięcie stanu równowagi pomiędzy popytem a podażą. Jednym z symptomów braku zrównoważenia jest zjawisko wykluczenia finansowego (financial exclusion), rozumianego jako całkowity lub częściowy brak dostępu do usług finansowych oferowanych przez rynek. Nadrew Lyshon i Nigel Thrift (w 1993 r.) jako jedni z pierwszych użyli tego terminu, opisując procesy uniemożliwiające klientom dostęp do systemu podstawowych usług finansowych. Można przyjąć, że przeciwieństwem zjawiska wykluczenia finansowego jest włączenie finansowe (financial inclusion), zwane również inkluzją finansową (integracją), które można opisać jako działania zmierzające do zapewnienia wszystkim grupom społecznym dostępu do systemu usług finansowych.

Inkluzja finansowa jest zjawiskiem, które można rozpatrywać w kontekście społecznym lub w nieco węższym, ekonomicznym. W ujęciu ekonomicznym inkluzja finansowa pełni kluczową rolę w walce z ubóstwem, co w dalszej perspektywie przekłada się na wzrost gospodarczy. Udział gospodarstw domowych w systemie finansowym przynosi pozytywne efekty dla całej społeczności. Nieprofesjonalni uczestnicy 
rynku kapitałowego mogąc korzystać $\mathrm{z}$ adekwatnych do ich potrzeb produktów oferowanych przez system usług finansowych, mają większe możliwości reagowania na zawirowania na rynku pracy oraz na rynku finansowym.

Wykluczenie finansowe można opisać jako odwrotność stanu, który określany jest jako finansowa integracja (inkluzja finansowa), a który został zdefiniowany przez Center for Financial Inclusion at Accion ${ }^{6}$ jako sytuacja, w której ogół społeczeństwa posiada pełen dostęp do usług finansowych dostarczanych klientom w akceptowalnej cenie, na dogodnych warunkach oraz z poszanowaniem ich godności. Usługi finansowe są zapewniane przez szereg instytucji, najczęściej prywatnych, i są dostępne dla wszystkich, którzy zechcą z nich korzystać, również dla osób niepełnosprawnych, niezamożnych, pochodzących z regionów wiejskich, a także wykluczonych społecznie.

Zjawisko wykluczenia finansowego poddano wielu analizom zarówno w kontekście perspektywy makroekonomicznej, jak i wpływu na stabilność finansową. Dostęp do usług finansowych jest ciągle aktualnym problemem w gospodarkach rozwijających się, niemniej państwa gospodarczo rozwinięte nadal prowadzą analizy, badania, poszukują adekwatnej metodologii umożliwiającej mierzenie tego zjawiska.

Szeroki dostęp do usług finansowych jest skorelowany z szeroko pojętym dobrem społecznym oraz korzyściami osób indywidualnych. Warto spojrzeć na proces ewolucji zjawiska, który jednocześnie z upływem czasu pociągnął za sobą zmianę jego definicji.

W późnych latach 80 . banki w ramach reorganizacji swoich usług i przyjęcia polityki ukierunkowanej na jakość świadczonych usług zadecydowały o wycofaniu z rynków krajów rozwijających części swoich oddziałów i skierowaniu działalności na pozyskanie nowych klientów w krajach rozwiniętych. Według Leyshona i Thriftego $^{7}$ (1993 r.) „wieloaspektowy proces restrukturyzacji korzyści” przeprowadzony przez banki oraz formalne instytucje finansowe dotknął również część Stanów Zjednoczonych oraz Wielką Brytanię. Banki wraz z wycofaniem usług finansowych z pewnych obszarów geograficznych pozbawiały niektóre grupy mieszkańców dostępu do swoich usług i produktów. Konsekwencją podjętych działań były narastające wśród klientów trudności w dostępie do systemu finansowego. Próby zdefiniowania zjawiska wykluczenia finansowego były i są podejmowane zarówno przez środowiska akademickie, jak i przez środowiska kształtujące politykę finansową. Badania empiryczne pokazują przyczyny zjawiska, co umożliwia tworzenie programów przeciwdziałających wykluczeniu. W badaniach oprócz metodologii istotne jest, która płaszczyzna

\footnotetext{
6 http://www.centerforfinancialinclusion.org/our-definition-of-financial-inclusion

7 The Restructuring of the UK Financial Services in the $1990 \mathrm{~s}$, red. A. Leyshon, N. Thrift, „Journal of Rural Studies" 9, 1993, s. 223-241, http://dx.doi.org/10.1016/0743-0167(93) 90068-U
} 
wykluczenia finansowego będzie przedmiotem eksploracji. Wykluczenie finansowe jest częścią szerszego zjawiska, jakim jest wykluczenie społeczne, które dotyka najbardziej wrażliwe grupy społeczne borykające się z dostępem do podstawowych świadczeń socjalnych, takich jak praca, dom, edukacja czy opieka zdrowotna. Niemniej nawet w takim ujęciu wykluczenie finansowe należy postrzegać jako zagadnienie wielowymiarowe.

Rozważając problem wykluczenia finansowego, istotne jest zdefiniowanie, czy zjawisko dotyczy braku dostępu do usług oferowanych przez system bankowy, czy też obejmuje sytuację, w której posiadacze kont bankowych nie korzystają z nich. Szybki rozwój procesów społeczno-ekonomicznych powoduje, że katalog czynników wpływających na wykluczenie finansowe wciąż pozostaje otwarty. A definicja zjawiska może podlegać ciągłym modyfikacjom. Definicja podana przez Stephena Sinlcaira w Financial Exclusion: An Introductory Survey ${ }^{8}$ w pełni wyczerpuje określenie zjawiska wykluczenia finansowego. Zdaniem autora wykluczenie finansowe to brak dostępu do podstawowych usług finansowych w ich właściwej formie. W ujęciu Leyshona i Thriftego wykluczenie finansowe to te procesy, które uniemożliwiają pewnym grupom społecznym i osobom indywidualnym dostęp do systemu finansowego. Przyczyną zjawiska są problemy z dostępem, warunki, koszty, rynek lub samowykluczenie, które stanowi odpowiedź na negatywne doświadczenia lub negatywne postrzeganie działalności banków.

Rozpatrując przyczyny wykluczenia finansowego, należy uwzględnić również globalizację, a przede wszystkim udział kapitału zagranicznego w systemie finansowym w Polsce. „Stopień umiędzynarodowienia usług finansowych jest więc u nas znacznie wyższy od norm zwyczajowo przyjętych w krajach o dojrzałej gospodarce rynkowej"9. Znaczny udział kapitału zagranicznego w polskim systemie finansowym nie wpłynął na obniżkę kosztów, jakie zobowiązany jest ponieść klient indywidualny, ani na zwiększoną dostępność kredytów dla małej przedsiębiorczości. Zastany przez zagraniczne instytucje finansowe stan jest na tyle dla nich korzystny, że nie podejmują one działań prowadzących do obniżenia kosztów leżących po stronie nieprofesjonalnego uczestnika rynku kapitałowego.

Rozważając zagadnienie wykluczenia finansowego, warto zwrócić uwagę na grupę, która podlega wykluczeniu finansowemu z powodu nadmiernego zadłużenia. Osoby, które miały dostęp do usług i produktów bankowych z powodu zobowiązań przekraczających ich możliwości finansowe, zostały odcięte od korzyści płynących

8 Financial Exclusion: An Introductory Survay, S. Sinclair, Centre for Research into Socially Inclusive, Edinburgh 2001.

9 System finansowy w Polsce, 2008, rozdz. XXII, op.cit. 
z posiadania konta. Stanowi to swoisty paradoks, ponieważ przyczyną tego rodzaju wykluczenia jest nadmierna konsumpcja, a nie niski dochód.

Zdiagnozowanie przyczyn wykluczenia finansowego jest nieodzowne w podjęciu działań, których celem będzie przeciwdziałanie zarówno samemu zjawisku, jak i jego skutkom. Szukając przyczyn wykluczenia finansowego, można wyróżnić dwa główne czynniki: trudności z dostępem do usług i produktów finansowych oraz bariery w korzystaniu z usług i produktów finansowych.

\subsection{Trudności z dostępem do usług i produktów finansowych}

Polityka prowadzona przez sektor bankowy wpływa bezpośrednio i pośrednio na proces wykluczenia finansowego. Zgodnie z założeniami tej polityki zdarza się, że banki odmawiają prawa do założenia rachunku bankowego ze względu na profil klienta. W ten sposób strona podażowa bezpośrednio kontroluje i wpływa na rynek swoich produktów i usług (rys. 2).

Innym czynnikiem, pośrednio kontrolującym rynek jest polityka lokalizacji placówek bankowych. Geograficzna dostępność do placówek bankowych determinuje możliwość uzyskania podstawowej usługi, jaką jest rachunek bankowy. Wydaje się, że w dobie postępującej cyfryzacji gęsta sieć placówek bankowych nie znajduje uzasadnienia. Należy jednak przyjąć, iż nie wszyscy klienci banków są użytkownikami internetu (szczególnie osoby starsze, spoza dużych ośrodków miejskich) i to właśnie oni są narażeni na wykluczenie finansowe w przypadku braku „okienka bankowego” w najbliższej okolicy.

Samowykluczenie klienta z systemu finansowego jest świadomą odmową korzystania nawet z podstawowej usługi świadczonej przez banki, jaką jest rachunek bankowy. U podstaw takich decyzji leżą różnorodne przyczyny. Zarówno te niezależne od nieprofesjonalnych uczestników rynku finansowego, przytoczone powyżej, jak i te zależne. Warto jednak zastanowić się, czy rozważając kwestię samowykluczenia, nie powinno się ograniczyć grupy czynników jedynie do tych determinantów, które wpływają na świadomy wybór klienta. Do takich można zaliczyć przesłanki behawioralne oraz deficyty w zakresie podstawowej wiedzy ekonomicznej. Rysunek 2 obrazuje wpływ strony podażowej (banki) na wykluczenie finansowe nieprofesjonalnych uczestników rynku finansowego. 
Rysunek 2. Trudności z dostępem do usług i produktów finansowych

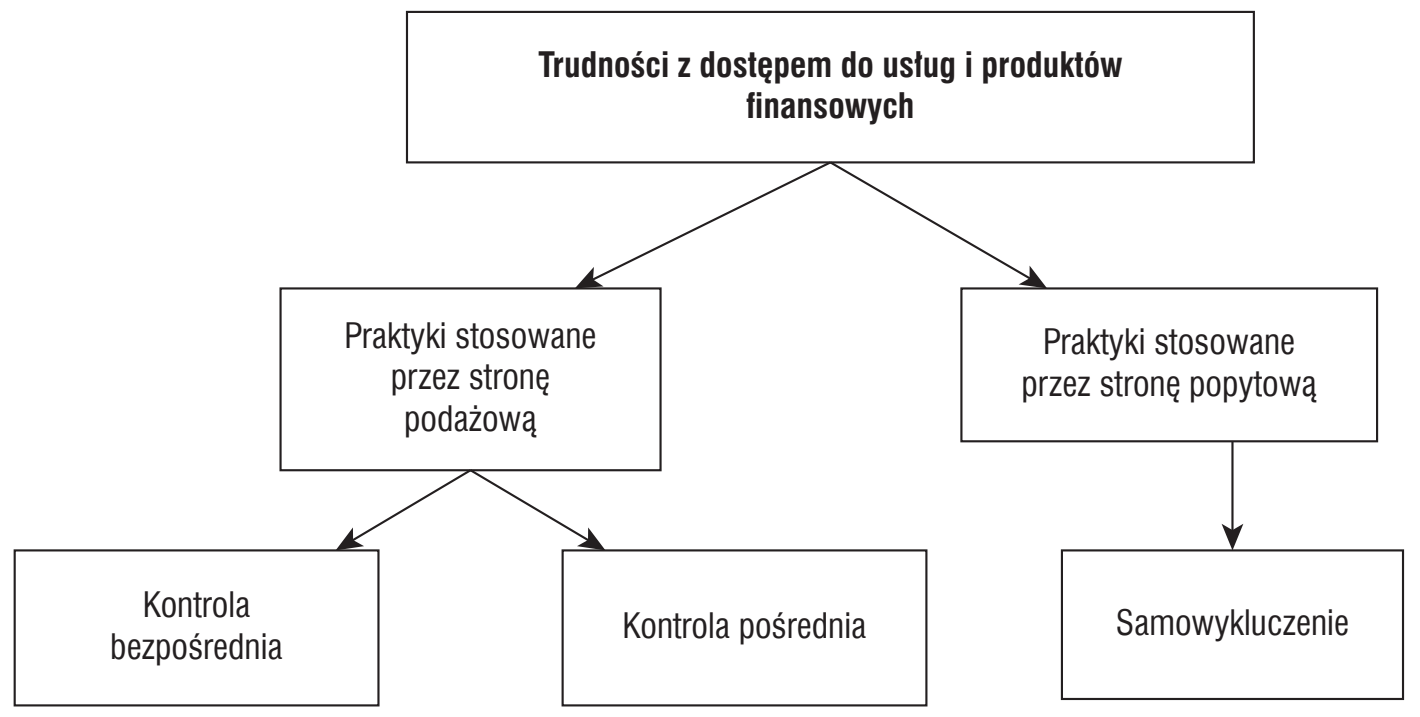

Źródło: Opracowanie własne.

\subsection{Bariery w korzystaniu z usług i produktów finansowych}

Narzędzia stosowane przez banki pozwalają na dokonanie oceny potencjalnego klienta nie tylko pod względem ryzyka kredytowego. Ewaluacja profilu klienta jest jednym z działań, które są wpisane w zarządzanie ryzykiem kredytowym. Inny jej aspekt to próba uniknięcia zobowiązań wobec klienta, którego obsługa mogłaby generować zbyt duże koszty dla banku. Oferowanie usług połączonych w taki sposób, by można było pobierać ukryte dodatkowe opłaty, lub narzucenie wyższych kosztów za częstsze korzystanie z niektórych usług to właśnie narzędzia, które można uznać za służące wyeliminowaniu niepożądanych klientów.

W relacji bank-klient ten ostatni jest słabszą stroną, szczególnie w sytuacji, gdy nie ma świadomości swoich praw. Dodatkowym elementem jest poczucie wstydu w przypadku nadmiernego zadłużenia lub groźby zajęcia nieruchomości w przypadku niespłacanych zobowiązań kredytu hipotecznego.

Odpowiedzią klientów na negatywne doświadczenia ze stroną podażową jest unikanie jakichkolwiek relacji z bankami. Brak rzetelnej informacji na temat przysługujących klientowi praw, a także brak podstawowej wiedzy ekonomicznej wzmaga poczucie wyalienowania z systemu finansowego. W takich przypadkach klienci szukają rozwiązania trudnych sytuacji poza systemem bankowym, stając się ofiarami instytucji działających na pograniczu prawa, bez możliwości ustawowej ochrony. Rysunek 3 ilustruje schematyczne ujęcie praktyk (zachowań) stosowanych przez banki oraz klientów indywidualnych. 
Rysunek 3. Bariery w korzystaniu z usług i produktów finansowych

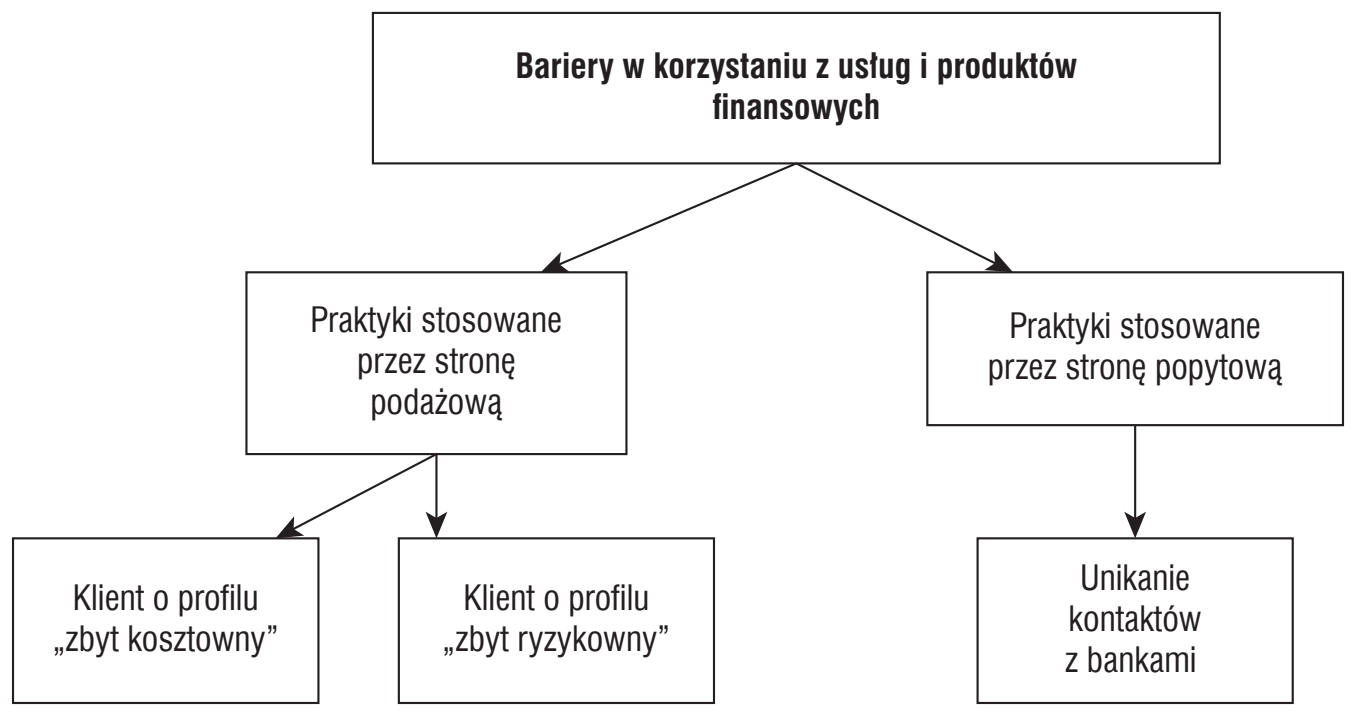

Źródło: Opracowanie własne.

Przedstawione opisy oraz ich schematyczne ujęcie obrazują przyczyny i wielowymiarowość wykluczenia finansowego. Usunięcie wszystkich barier, zarówno tych dotyczących dostępu do usług i produktów finansowych, jak i tych stanowiących przeszkodę w korzystaniu np. z podstawowej usługi, jaką jest konto bankowe, nie spowoduje automatycznie stuprocentowego zniesienia wykluczenia finansowego. Rysunek 1 pokazuje, że strona podażowa i strona popytowa to dwie strony tego samego „medalu” i obydwie strony odpowiadają za przyczyny wykluczenia. Jednak stopień tej odpowiedzialności nie rozkłada się równomiernie.

To strona podażowa dysponuje narzędziami, które wpływają pozytywnie na działania i decyzje klientów. Istotna jest infrastruktura rozumiana jako regulacje prawne, sieć oddziałów banków, a także dostęp do narzędzi typu bankomaty, terminale płatnicze itp. (katalog może być uzupełniany w miarę rozwoju urządzeń teleinformatycznych).

Z kolei strona popytowa, reprezentowana przez klienta rozumianego również jako gospodarstwo domowe (wspomniany wcześniej nieprofesjonalny uczestnik rynku kapitałowego), a także małe lub średnie przedsiębiorstwo o charakterze rodzinnym zanim skorzysta $z$ danej usługi, bądź nabędzie jakikolwiek produkt, jest poddana weryfikacji sprawdzającej jej profil. Natomiast samodzielna decyzja klienta będzie się opierała na przesłankach ekonomicznych oraz behawioralnych.

Polityka banków, w ramach której odmawia się klientom otwarcia konta bankowego, kwestia fizycznej dostępności do punktów, gdzie świadczone są usługi finansowe, bądź przyjęta polityka marketingowa, to czynniki decydujące o wykluczeniu lub włączeniu finansowym. Likwidacja oddziałów banków w rejonach zamieszkałych przez niezamożne grupy mieszkańców wpływa na geograficzne ograniczenie 
dostępności usług bankowych. Omówione bariery korzystania z usług i produktów finansowych (przedstawione schematycznie na rys. 3) prowadzące do samowykluczenia z systemu finansowego są konsekwencją braku odpowiedniej dla klienta oferty. Inną istotną przesłanką przyczyniającą się do wykluczenia finansowego są zbyt wysokie opłaty manipulacyjne pobierane przez banki z tytułu np. prowadzenia konta, udzielania kredytów, pożyczek.

\section{Typologia wykluczenia finansowego}

Analizując przyczyny wykluczenia finansowego, należy wziąć pod uwagę kilka determinantów tego zjawiska. Wykluczenie finansowe może dotyczyć wyłącznie jednej z płaszczyzn systemu finansowego, dostępnego dla klientów indywidualnych.

Wykluczenie finansowe jest bardzo ogólnym pojęciem, które obejmuje wiele poziomów. Analiza zjawiska pozwoli na zdiagnozowanie jego rodzaju i zasięgu, a także czynników je powodujących. Każdy z przedstawionych poniżej typów wykluczenia finansowego jest wykluczeniem bankowym, a celem zaprezentowanej typologii jest wskazanie stopnia i poziomu zjawiska. Ponadto analizując poszczególne typy, warto zadać sobie pytanie, czy w przypadku np. wykluczenia kredytowego można jeszcze mówić o wykluczeniu finansowym, czy jedynie o braku dostępu do tego produktu.

Tabela 1. Sektor bankowy w Polsce w liczbach

\begin{tabular}{|l|r|r|r|r|r|}
\hline \multicolumn{1}{|c|}{ Wyszczególnienie } & 2012 & 2013 & 2014 & 2015 & 2016 \\
\hline Banki komercyjne & 45 & 41 & 38 & 38 & 36 \\
\hline Banki spółdzielcze & 572 & 571 & 565 & 561 & 558 \\
\hline Oddziały instytucji kredytowych & 25 & 28 & 28 & 27 & 27 \\
\hline Liczba placówek & 15412 & 15297 & 15062 & 14496 & 14476 \\
\hline
\end{tabular}

Źródło: KNF, Raport o sytuacji banków 2016.

\subsection{Wykluczenie bankowe}

Ten rodzaj wykluczenia jest najbardziej rozpoznawalny w kontekście wykluczenia finansowego. Wykluczenie w tym aspekcie obejmuje brak dostępu do konta bankowego, brak dostępu do określonego typu instytucji oferujących podstawową formę konta oraz brak dostępu do usług powiązanych z kontem bankowym. Wskaźniki diagnozujące jego poziom pokazują odsetek populacji danego państwa w wieku powyżej 15 lat, który nie ma dostępu do konta w banku lub innej instytucji finansowej. 
Podstawowe konto bankowe jest uważane za dobro, do którego każdy członek danej społeczności powinien mieć dostęp. We współczesnych społeczeństwach brak możliwości korzystania z konta bankowego może „stygmatyzować” jednostkę. Niemożliwe staje się korzystanie $\mathrm{z}$ wszelkich form płatności bezgotówkowych, otrzymywanie świadczeń, bezpieczne przechowywanie gotówki, dokonywanie przelewów. W kontekście posiadania konta bankowego istotne jest pytanie, czy sam dostęp do tej usługi stanowi o kryterium finansowej inkluzji.

Wykluczenie bankowe to brak możliwości otrzymywania na konto osobiste regularnych, elektronicznych przelewów, do których zaliczamy m.in. pensje, emerytury, świadczenia socjalne, niemożność dokonywania płatności za towary i usługi w formie bezgotówkowej, np. brak możliwości zakupów w sieci. Należy również zwrócić uwagę na możliwość bezpiecznego deponowania gotówki.

Badając stopień wykluczenia bankowego, warto zwrócić uwagę na wskaźniki, które posłużą do badania tego zjawiska. Czy badanie obejmie jedynie osoby, czy gospodarstwa domowe? Czy jedna osoba bez dostępu do konta bankowego pozostająca $\mathrm{w}$ gospodarstwie domowym $\mathrm{z}$ innymi, którzy taki dostęp posiadają, determinuje to gospodarstwo jako wykluczone bankowo? Czy w takim przypadku ocena powinna dysponować skalą od wykluczenia pełnego do wykluczenia częściowego? Kolejnym kryterium oceny powinna być częstotliwość korzystania z konta bankowego oraz infrastruktura, która ułatwia dostęp do usług bankowych.

Istotnym elementem, który wpływa na poziomu wykluczenia bankowego lub całości zjawiska wykluczenia finansowego, jest profil osób wykluczonych. Wśród danych, które mogą posłużyć do oceny, należy wziąć pod uwagę: status rodzinny, status społeczno-zawodowy, płeć, wiek, narodowość, wykształcenie, rodzaj zatrudnienia i wysokość dochodu, długość zamieszkiwania pod tym samym adresem, formę własności zajmowanego mieszkania/domu. Ponadto przytoczone determinanty określające profil osoby wykluczonej mogą przyczynić się do stworzenia „na miarę” produktów/usług bankowych.

W badaniach poziomu wykluczenia finansowego pasywni posiadacze kont, którzy nie wykorzystują możliwości, jakie daje dostęp do tej podstawowej usługi finansowej, nie są zaliczani do grupy osób wykluczonych. Niemniej powstaje wątpliwość, czy wykluczenie bankowe to brak dostępu do usług finansowych, czy ekskluzja obejmuje też pasywnych posiadaczy kont.

Wykluczenie bankowe rodzi konsekwencje dla bezpośrednio zainteresowanych zarówno w sferze społecznej, jak i ekonomicznej. Osoby bez konta bankowego napotykają problemy natury administracyjnej, np. brak możliwości przekazywania na konto świadczeń. Ponadto mogą doświadczać poczucia wykluczenia społecznego, utracić 
kontrolę nad osobistym budżetem, mieć problemy z zapewnieniem bezpieczeństwa finansowego w przypadku relokacji gotówki.

Do skutków ekonomicznych można zaliczyć wyższe koszty transakcji bankowych dla osób nieposiadających konta bankowego, utratę potencjalnych korzyści, jakie dają transakcje kartą kredytową (rabaty, punkty itp.).

Rysunek 4 obrazuje wzrost liczby rachunków bieżących gospodarstw domowych w Polsce na przestrzeni lat 2010-2015. Polska zgodnie z danymi World Bank Group przedstawionymi na rysunku 5 zajmuje jedno z pierwszych miejsc pod względem odsetka osób posiadających rachunki bankowe w wybranych krajach UE w 2014 r. Biorąc przedstawione dane pod uwagę, można stwierdzić, że w Polsce mamy stosunkowo niski poziom wykluczenia finansowego. Niemniej warto zwrócić uwagę na zaprezentowane czynniki ukazujące wielowymiarowość zjawiska, które oprócz cech ekonomicznych ma także cechy społeczne.

Rysunek 4. Liczba rachunków bieżących gospodarstw domowych w złotych prowadzonych przez banki, oddziały instytucji kredytowych i SKOK-i w Polsce (w tys.) w latach 2010-2015

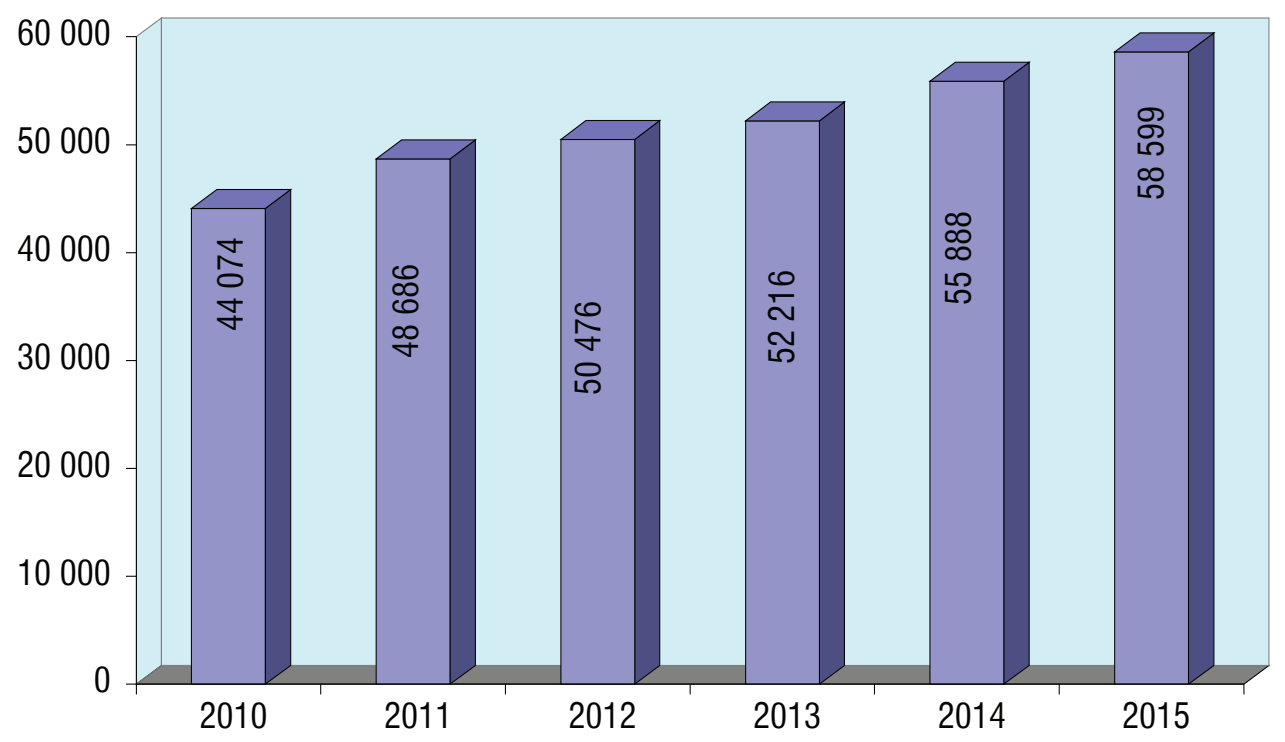

Źródło: Dane NBP.

W aspekcie konsumpcji kredyt jest narzędziem pozwalającym na nabycie dóbr, których koszt przewyższa wysokość dochodu. Natomiast w aspekcie socjalnym kredyt może pełnić pozytywną rolę, o ile jest wykorzystany na zdobywanie wykształcenia, doskonalenie zawodowe itp., co w przyszłości może prowadzić do uzyskania wyższych dochodów lub społecznej inkluzji. 
Rysunek 5. Odsetek osób posiadających rachunki bankowe w wybranych krajach UE w 2014 r. (w \%)

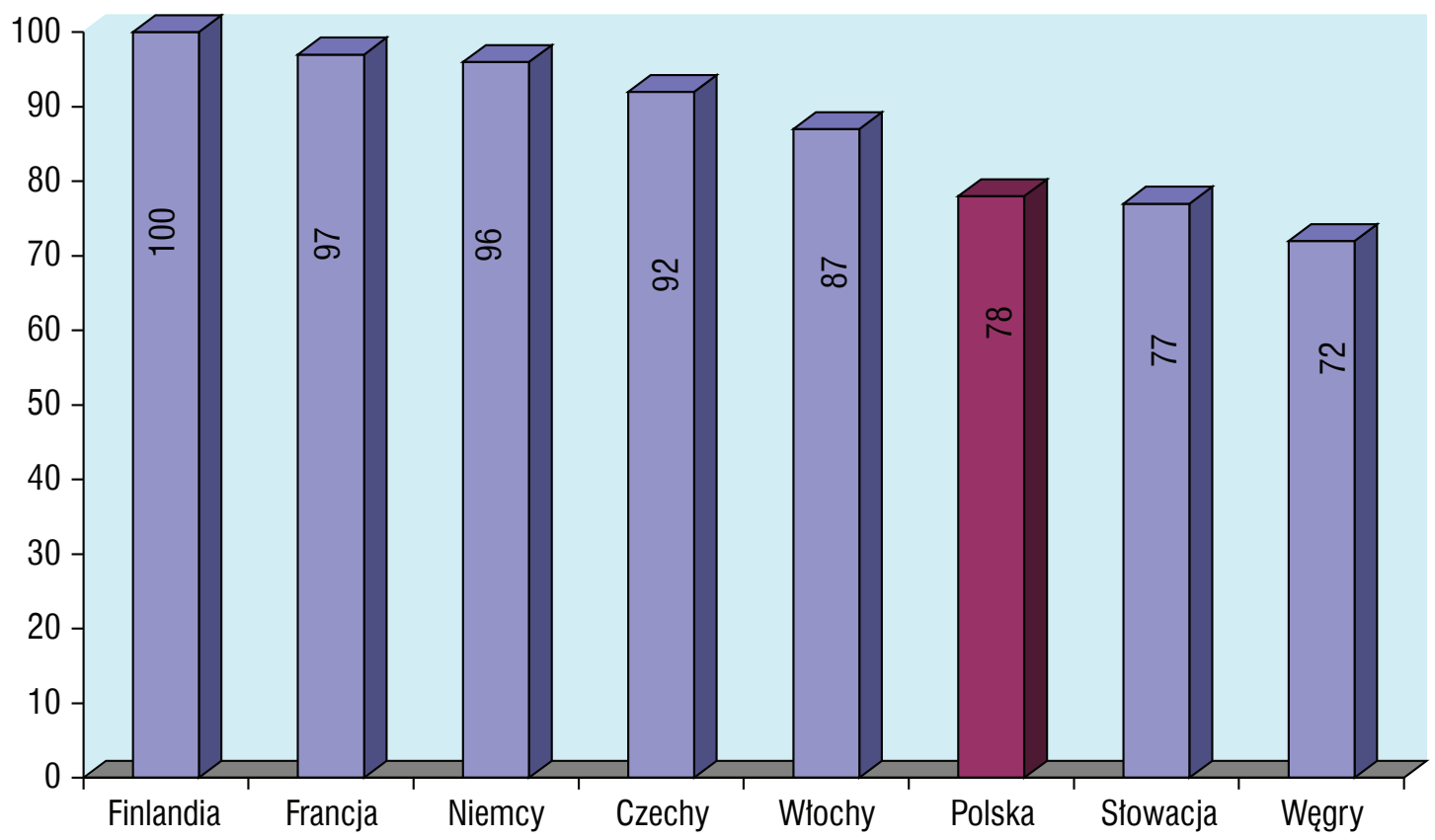

Źródło: Dane World Bank Group.

\subsection{Wykluczenie kredytowe}

Wykluczenie kredytowe to kolejny rodzaj wykluczenia finansowego. Elementy opisujące ten typ wykluczenia to brak możliwości uzyskania kredytu lub pożyczki, polityka instytucji oferujących kredyty, rodzaj kredytu.

Wykluczenie kredytowe podobnie jak wykluczenie bankowe rodzi konsekwencje zarówno na płaszczyźnie społecznej, jak i ekonomicznej. Skutki społeczne tego rodzaju wykluczenia, które przejawia się brakiem dostępu do systemu kredytów, mogą wpływać na sferę życia zawodowego oraz na jakość życia. Brak środków na kształcenie może znacząco oddziaływać na aktywizację zawodową, pozbawiając możliwości czynnego poszukiwania pracy. Jakość życia uzależniona jest od zaspokojenia nie tylko podstawowych potrzeb życiowych.

Niemniej posiadanie źródeł finansowania zakupu bądź wynajmu mieszkania, zabezpieczenie usług medycznych to podstawowe obszary życia codziennego, które wymagają nakładów finansowych. Niemożność uzyskania kredytu w banku popycha klienta w kierunku nieformalnych instytucji pożyczkowych.

Co prawda wolumen kredytów udzielonych w latach 2010-2016 (rys. 6) wykazuje tendencję wzrostową, jednak zaostrzenie wymogów przy udzielaniu kredytów spowodowało, że wielu klientów zwróciło się do instytucji pożyczkowych spoza systemu bankowego, szczególnie w sytuacji konieczności uzyskania szybkiego dostępu 
do środków finansowych. Niejednokrotnie stało się to przyczyną tzw. pętli zadłużenia, co w konsekwencji może doprowadzić do wykluczenia finansowego.

Wykluczenie kredytowe stwarza dogodne warunki do powstawania firm pożyczkowych działających równolegle do systemu bankowego, jednak poza regulacjami prawnymi chroniącymi klientów. Desperacja klientów, którzy nie uzyskali kredytu lub pożyczki w instytucjach włączonych w system bankowy ze względu na brak zdolności finansowej, jest czynnikiem przysłaniającym ryzyko, jakie generują dla swych klientów firmy pożyczkowe nieobjęte regulacjami prawnymi chroniącymi konsumentów. Należałoby postawić tu pytanie, czy taka sytuacja może wygenerować ryzyko dla systemu bankowego.

Rysunek 6. Kredyty dla gospodarstw domowych (brutto w mld zł)

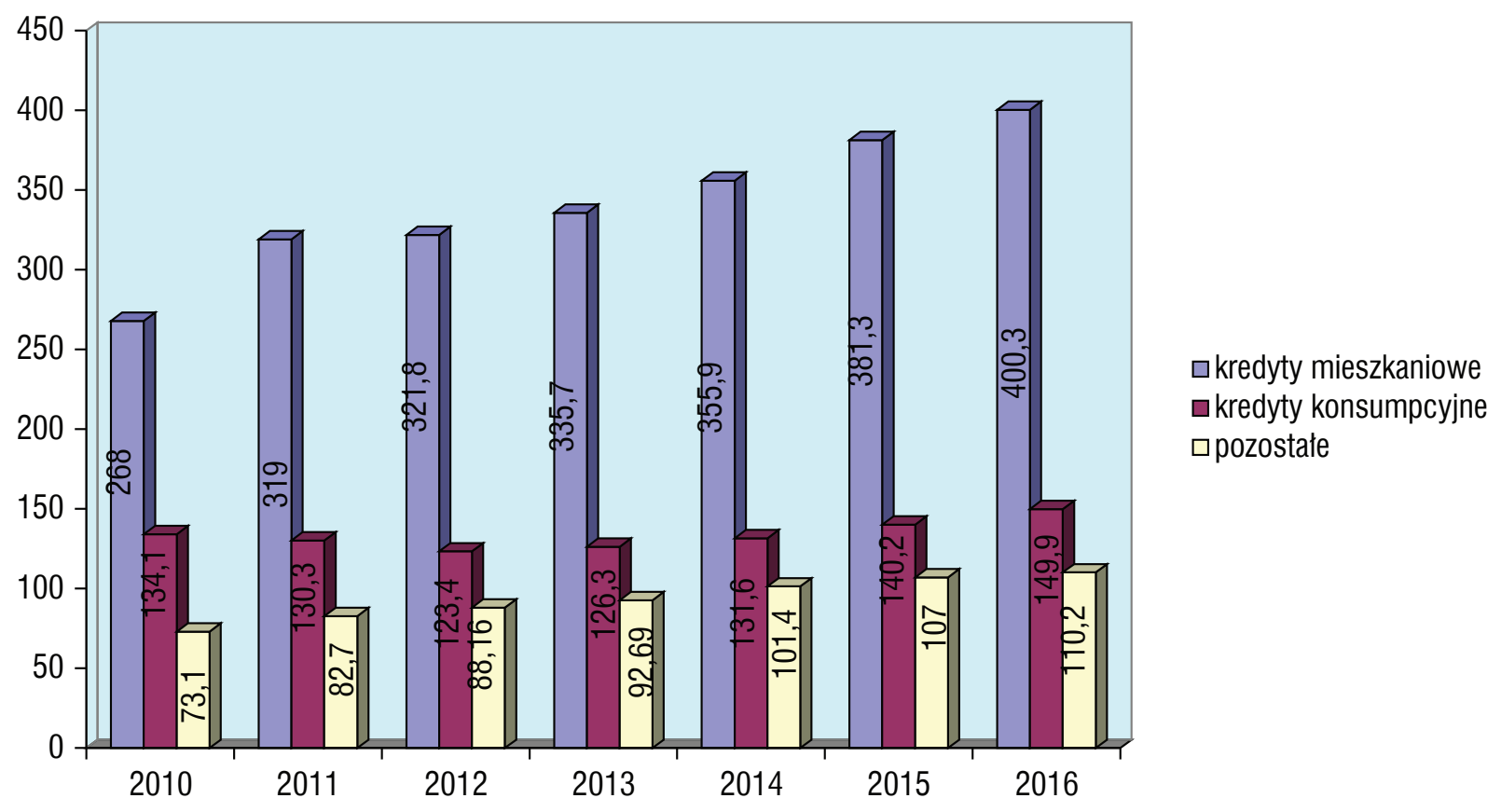

Źródło: Jak do rys. 5.

\subsection{Wykluczenie z systemu oszczędzania}

Brak dostępu do konta oszczędnościowego może być uznany za jeden ze wskaźników wykluczenia z systemu oszczędzania. Aczkolwiek nie jest to czynnik determinujący w stopniu zasadniczym zaliczenie jednostki bez dostępu do podstawowego konta oszczędnościowego do grupy osób wykluczonych finansowo. Klienci o wyższym poziomie wiedzy ekonomicznej coraz częściej budują strukturę swoich oszczędności poza systemem bankowym. Trudno w tym przypadku określić ich jako grupę zagrożoną wykluczeniem z systemu oszczędzania bądź wykluczeniem finansowym. 
Rysunek 7 ukazuje wzrost wolumenu depozytów gospodarstw domowych, co można zinterpretować jako dowód na popularność lokat oszczędnościowych w Polsce. Niemożność korzystania z konta oszczędnościowego może się przełożyć na ocenę zdolności finansowej, a także na dostęp do bardziej rozbudowanych produktów bankowych.

O popularności produktów oszczędnościowych decyduje ich jakość i dopasowanie do potrzeb oraz profilu klienta. Brak oferty produktów o większym stopniu zaawansowania niż podstawowe konto oszczędnościowe może wpłynąć na zmniejszenie liczby klientów korzystających z oferty banku.

Rysunek 7. Wartość depozytów gospodarstw domowych (w mld zł)

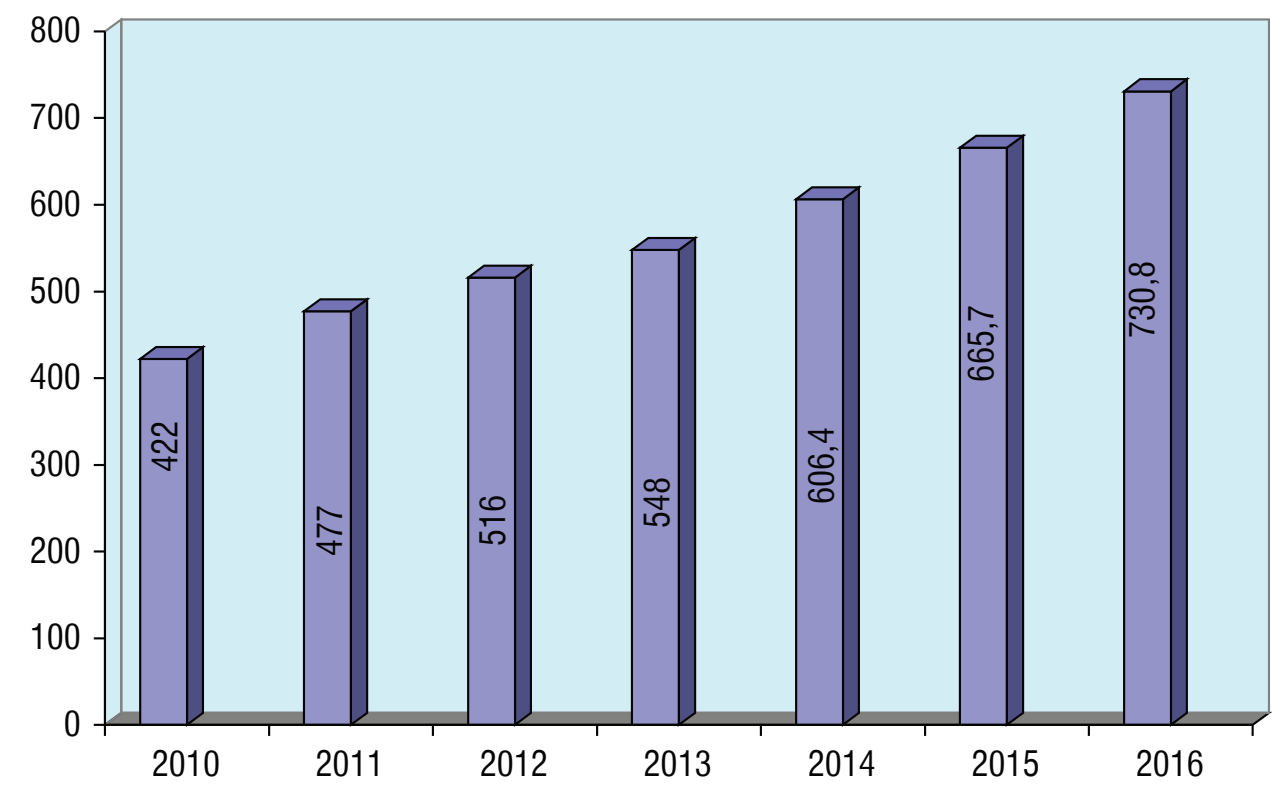

Źródło: Jak do rys. 5.

\section{Analiza przyczyn wykluczenia finansowego}

\subsection{Przyczyny wykluczenia bankowego}

Przyczyny wykluczenia bankowego, jak pokazano na rysunkach 2 i 3, leżą zarówno po stronie podażowej, jak i popytowej. Banki, podejmując decyzję o zamknięciu konta, kierują się najczęściej takimi przesłankami, jak niedostateczna liczba transakcji przeprowadzonych przez posiadacza konta w określonym czasie.

Najbardziej narażeni na konsekwencje takiej polityki banków są wspomniani klienci pasywni. Kolejnymi faktorami, które determinują dalszą współpracę na linii 
klient-bank, są: niski poziom dochodu klienta lub brak wpływu środków na konto, brak stałego miejsca zamieszkania, brak kontaktu z klientem. Analizując przyczyny wykluczenia bankowego, należy wziąć pod uwagę rolę banku, jako podmiotu inicjującego podjęcie współpracy z klientami pozostającymi poza systemem bankowym. Mowa tu o działaniach skierowanych do byłych klientów, którzy z różnych przyczyn, m.in. ekonomicznych, znaleźli się poza systemem bankowym, jak i do osób, które nigdy nie były klientami banków (szczególnie osoby starsze, spoza dużych ośrodków miejskich oraz tzw. młodzi dorośli). Nadmierne zadłużenie klienta to kolejny element przyczyniający się do wykluczenia bankowego. Nie bez znaczenia jest również oferta dedykowana klientom oraz polityka banków.

Nieadekwatny rodzaj świadczonych usług, geograficzne ograniczenia, brak dopasowania oferty do potrzeb klienta, sposób dostarczania usług wpływają bezpośrednio na poziom wykluczenia bankowego.

Wysokość kosztów transakcji bankowych ponoszonych przez klientów rzutuje na decyzję o otwarciu i korzystaniu z konta bankowego. Nadal wśród osób mniej zamożnych panuje przekonanie, że konto bankowe jest niedostępne dla ubogich. Niemniej należy zwrócić uwagę, że w badaniu przeprowadzonym w 2008 r. przez EU SILC tylko znikoma liczba respondentów nie posiadała konta bankowego z powodu kosztów związanych z jego prowadzeniem. Znacznie większy odsetek badanych wskazał jako przyczynę rezygnacji z konta brak potrzeby jego posiadania.

W dobie rozwoju internetu oraz nowych technologii klienci szukają dostawców usług bankowych, którzy oferują płatności elektroniczne lub przez telefon.

Wśród czynników behawioralnych wpływających na decyzję klienta dotyczącą otwarcia konta bankowego można także zaliczyć brak zaufania do banków, obawę utraty kontroli nad finansami lub uwarunkowania kulturowe.

\subsection{Przyczyny wykluczenia kredytowego}

Strona podażowa kieruje się następującymi czynnikami, które decydują o odmowie udzielenia kredytu lub pożyczki: brak historii kredytowej/bankowej, niekorzystna historia kredytowa/bankowa, inne zobowiązania kredytowe zaciągnięte przez klienta, brak wystarczającego zabezpieczenia, brak stałego miejsca zamieszkania, trudne relacje bank-klient, brak oficjalnych/legalnych dochodów.

Poza wymienionymi należy wskazać jeszcze brak odpowiedniej dla klienta oferty kredytowej. Banki, przyjmując strategię działalności kredytowej, dążą w najwyższym stopniu do minimalizacji wartości portfela kredytów zagrożonych. Niemniej uwzględniając także bezpieczeństwo finansowe klienta, starają się nie dopuścić do 
nadmiernego zadłużenia klientów, które może przyczynić się do wykluczenia finansowego w podstawowym znaczeniu tego zjawiska.

Elementarnym czynnikiem przesądzającym o decyzji klienta dotyczącym zaciągnięcia kredytu jest potrzeba dodatkowych środków finansowych lub dochody zbyt niskie, by pokryć koszty planowanego zakupu lub inwestycji. Tak więc potrzeba pożyczania jest jednym z podstawowych czynników leżących po stronie popytowej. Inne przyczyny wykluczenia kredytowego zdeterminowane przez stronę popytowa to: niechęć do pożyczania, skłonności do oszczędzania, co pozwala na zakupy towarów za zgromadzoną gotówkę bez konieczności kredytowania. Do pozostałych można także zaliczyć takie czynniki, jak brak zaufania do banków, przekonanie, że kredyt nie jest dla osób ubogich czy obawa przed utratą kontroli nad finansami.

\subsection{Przyczyny wykluczenia z systemu oszczędzania}

Wśród istotnych elementów podażowych wpływających na wykluczenie z systemu oszczędzania należy wymienić czynnik geograficzny, który najbardziej determinuje dostępność do wszelkiego rodzaju usług i produktów oferowanych przez system finansowy. Innym faktorem, za który w sposób bezpośredni odpowiadają banki, jest struktura oferowanego produktu oszczędnościowego oraz sposób świadczenia usługi.

Dosyć powszechne, szczególnie wśród niezamożnej części społeczeństwa, jest przekonanie, że oszczędzanie nie jest dla osób o niskich dochodach, co w znacznym stopniu wpływa na decyzje dotyczące korzystania nawet z podstawowego konta oszczędnościowego. Brak zaufania do banków i instytucji finansowych ma wpływ również na podejmowane decyzje. Innym faktorem, mimo że o marginalnym znaczeniu, ale powiązanym z brakiem zaufania do banków, jest czynnik kulturowy, który tak jaki wskazane elementy powinien być uwzględniony przez przygotowujących oferty usług i produktów bankowych dla szerokiego kręgu odbiorców.

\section{Podsumowanie}

Działania banków w sferze promocji powinny koncentrować się nie tylko na profilu zasobnego klienta, ale także objąć swoją akcją klientów o niższych dochodach. Rolą strony podażowej jest prowadzenie badań w celu identyfikacji potrzeb potencjalnych konsumentów. W kompetencjach banków jest przygotowanie produktu „skrojonego na miarę” potrzeb danych grup społecznych, z uwzględnieniem rejonów zamieszkałych przez mniej zamożnych mieszkańców (np. obszary o mniejszym 
stopniu zurbanizowania). Z jednej strony najnowsze osiągnięcia w dziedzinie technologii pozwalają na zastosowanie narzędzi obniżających koszty usług bankowych, $\mathrm{z}$ drugiej strony istnieje wciąż grupa klientów przywiązana do tradycyjnych form świadczenia usług (np. osoby starsze).

Zjawisko wykluczenia finansowego nie jest jedynie brakiem dostępu do konta bankowego. Przedstawiona analiza ukazuje, że zagadnienie powinno być rozpatrywane na kilku płaszczyznach. Można zadać sobie pytanie, czy brak możliwości zaciągnięcia kredytu lub pożyczki pozycjonuje klienta w gronie osób wykluczonych finansowo? Z przedstawionych czynników powodujących wykluczenie finansowe wynika, że istotny jest dochód oraz wiedza z zakresu zagadnień finansowych.

Problem wykluczenia finansowego nie kończy się w momencie otwarcia konta bankowego. Zjawisko ma szerszy kontekst i stawia wiele zadań głównie przed stroną podażową. Szczególnym wyzwaniem dla sektora bankowego jest grupa społeczna o niskich dochodach.

Istotne wydaje się również, by banki wzięły na siebie odpowiedzialność za kampanie promujące wiedzę z zakresu finansów. Ważną grupę docelową stanowią osoby o niskim poziomie wiedzy ekonomicznej. To właśnie one są najbardziej narażone na zagrożenia generowane przez podmioty niepodlegające nadzorowi bankowemu. Obowiązkiem pracowników banków mających bezpośredni kontakt $\mathrm{z}$ klientem (front line) powinno być oferowanie produktów i usług zgodnych z możliwościami finansowymi nabywcy.

Odpowiadając na pytanie postawione na wstępie artykułu, można stwierdzić, że minimalizowanie skutków wykluczenia finansowego wymaga działań wykraczających poza propozycję otwarcia konta. Natomiast planowanie kampanii promocyjnych nie może ograniczać się jedynie do prezentacji produktów, dzięki którym będą pozyskani nowi klienci.

\section{Literatura}

Banking the World. Empirical Foundations Of Financial Inclusion, red. R. Cull, A. Demirguc-Kunt, J. Morduch, Massachusetts Institute of Technology, Cambridge 2013.

Financial Exclusion: An Introductory Survey, Center for Research into Socially Inclusive, Edinburgh 2001.

Małecki W., Regulacje sektora bankowego. Zmieniona wersja opracowania przygotowanego w ramach projektu „Banki a cykle koniunkturalne” finansowanego ze środków Narodowego Centrum Nauki przyznanych na podstawie decyzji numer DEC-2011/01/B/ HS4/06216. 
Measuring Financial Inclusion around the World, red. A. Demirguc-Kunt, L. Klapper, D. Singer, P. Van Oudheusden, The Global Findex Database, World Bank Group, Washington 2014.

New Frontiers in Banking Services. Emerging needs and tailored products for Untapped Markets, red. L. Anderloni, M.D. Braga, E.M. Carluccio, Springer-Verlag, Berlin Heidelberg 2007.

Porównanie wybranych elementów polskiego systemu płatniczego z systemami innych krajów Unii Europejskiej za 2013 r., NBP, Departament Systemu Płatniczego, Warszawa 2014.

System finansowy w Polsce, red. nauk. B. Pietrzak, Z. Polański, B. Woźniak, PWN, Warszawa 2006.

System finansowy w Polsce, red. nauk. B. Pietrzak, Z. Polański, B. Woźniak, wyd. II, PWN, Warszawa 2008.

Sytuacja makroekonomiczna w Polsce na tle procesów w gospodarce światowej-Rynki finansowe, GUS, Departament Studiów Makroekonomicznych i Finansów, Warszawa 2015.

Zielona księga w sprawie detalicznych usług finansowych. Lepsze produkty, szerszy wybór i większe możliwości dla konsumentów i przedsiębiorstw, Bruksela, 10.12.2015 r., COM (2015) 630 wersja ostat.

http://www.centerforfinancialinclusion.org/

\section{Financial Exclusion and Financial Integration: Terminological Aspects}

The aim of the article was to present the issue of financial exclusion and define sensitive areas of this phenomenon. The factors that may be relevant for measuring the degree of financial exclusion were analysed. An attempt was also made to determine the difficulties in access to financial services in the context of practices applied by both the supply and demand sides. In addition, barriers to the use of services were analysed as were financial products in terms of practices used by supply and demand. The typology of financial exclusion presented in the article is an attempt to define the type and scope of the phenomenon. Bank exclusion, credit exclusion and exclusion from the savings system are financial exclusion indicators. Each of those types of exclusion affects the economic and social level. Financial exclusion, which is one of the symptoms of the imbalance between demand and supply, is understood here as total or partial access to financial services offered by the market. The article also attempts to analyse the causes of exclusion with the division into supply and demand factors. The typology of financial exclusion proposed in the article may be a contributing factor to the reverse phenomenon, which is financial inclusion. 
Keywords: financial exclusion, financial inclusion, typology of financial exclusion, financial exclusion factors, bank exclusion, credit exclusion, degree of financial exclusion

\section{L'exclusion financière et l'intégration financière - les aspects terminologiques}

Le but de l'article était de présenter la question de l'exclusion financière et de définir des zones sensibles de ce phénomène. On a procédé à l'analyse des facteurs pouvant être pertinents pour mesurer le degré d'exclusion financière. On a également tenté de déterminer les difficultés d'accès aux services financiers dans le contexte des pratiques appliquées du côté de l'offre et de la demande. En outre, les obstacles à l'utilisation des services et des produits financiers ont été analysés, également en termes de pratiques utilisées du côté de l'offre et de la demande. La typologie de l'exclusion financière présentée dans l'article cherche à définir le type et la portée du phénomène. L'exclusion bancaire, l'exclusion de crédit et l'exclusion du système d'épargne sont des indicateurs de l'exclusion financière. Chacun des types d'exclusion cités a des effets sur le plan économique et social. Le phénomène de l'exclusion financière, qui est l'un des symptômes du déséquilibre entre la demande et l'offre, est compris comme un accès total ou partiel aux services financiers offerts par le marché. L'article tente également d'analyser les causes de l'exclusion ventilées par facteurs de l'offre et de la demande. La typologie du phénomène de l'exclusion financière proposée dans l'article peut contribuer au phénomène inverse, à savoir l'inclusion financière.

Mots-clés: exclusion financière, inclusion financière, typologie de l'exclusion financière, facteurs de l'exclusion financière, exclusion bancaire, exclusion de crédit, degré de l'exclusion financière

\section{Финансовое исключение и финансовая интеграция - терминологические аспекты}

Цель статьи - указать проблему финансовой изоляции и определить особо важны аспекты этого явления. Анализу подверглись факторы, которые могут иметь значение для измерения степени финансового исключения. Была также предпринята попытка выявить трудности с доступом к финансовым 
услугам, в контексте практики, применяемой как со стороны спроса, так и со стороны предложения. Кроме того, были проанализированы барьеры использования услуг и финансовых продуктов также с точки зрения применяемых мер как по линии спроса, так и по линии предложения. Представленная в статье типология финансового исключения является попыткой указания вида и масштаба этого явления. Банковское исключение, кредитное исключение и исключение из системы накопления сбережений - это показатели финансового исключения. Каждое из них отражается на экономическом и социальном уровнях. Финансовое исключение, которое является одним из симптомов дисбаланса между спросом и предложением, понимается как полный или частичный доступ к финансовым услугам, предлагаемым рынком. В статье автор также попытался проанализировать причины исключения, выделяя факторы со стороны предложения и спроса. Предложенная в статье типология феномена финансового исключения может способствовать обратному явлению - финансовому включению.

Ключевые слова: финансовое исключение, финансовое включение, типология финансового исключения, факторы финансового исключения, банковское исключение, кредитное исключение, степень финансового исключения 